International Journal of Management Science and

Business Administration

Volume 2, Issue 8, July 2016, Pages 42-51

DOI: $10.18775 /$ ijmsba.1849-5664-5419.2014.28.1005

URL: http://dx.doi.org/10.18775/ijmsba.1849-5664-5419.2014.28.1005

\title{
A Multifarious, Multifaceted Approach to the Multipolar World: a Necessity
}

\author{
${ }^{1}$ Petar Kurečić, ${ }^{2}$ Binoy Kampmark \\ ${ }^{1}$ University North, Koprivnica, Trg Žarka Dolinara 1, Croatia \\ ${ }^{2}$ The Royal Melbourne Institute of Technology University, 124 La Trobe Street, Melbourne, Australia
}

\begin{abstract}
If we compare today's world with the World (s) from 1914, 1929 or 1939, some similarities occur: multiple powerful actors on the global and regional levels with conflicting interests, economic difficulties of a large number of economies, and the inability of "the international community" to put a stop on the world's most intense conflicts or rivalries. The Great Recession, which hit the developed economies, especially European economies the hardest, has shifted more economic power into the direction of emerging economies, thereby, accelerating an inevitable economic and political change. Various states have managed to accelerate the change in the distribution of economic wealth. These states, grouped mainly in the BRICS, and in the Next Eleven (N11) have shown, contrary to the Western, "culturally superior" geopolitical thought that they are neither backward nor incompetent. They challenge the developed states. After the paradigm of American Empire, which ended in the worst economic crisis in 70 years, there came time for a new paradigm. It might be an illusion to think that multipolarity would be shaped by all the parties concerned, it has to be shaped by the most important ones. However, the current relations between most powerful states are all but cooperative. The pragmatic relations and the common goals of the BRICS states should not be overestimated. The relations between the USA and the EU, which show a high level of homogeneity because of the Ukrainian crisis, may not be so close in the future. A clear difference would exist between the arranged and the accepted multi-polarity, and a multi-polarity in which one side is not inclined but compelled to accept multipolarity, concurrently limiting its achievements. An approach to the present and the future multipolarity and multipolar world that would be multifarious and multifaceted is therefore a necessity.
\end{abstract}

Keywords: Multifaceted and Multifarious Approach, World Economy, Uneven and Combined Development, Multipolarity

\section{Introduction}

Hegemony historically has operated to soften the tensions between the internationalist imperatives of capitalism and the nationalist interests of nation-states. A hegemonic power has an incentive to force other nations to abandon their national capitalism and economic controls and accept a world of free trade, free capital flows, and free currency convertibility. This is so because world's dominant economic power has the most to gain from such a free world and the most to lose from nationalist efforts to limit the free movement of capital, goods, and currenciesi (Mercille, 2008: 57-58).

After the fall of the Soviet Union, the international democratic order was rewritten by the US. By openly appropriating the universal in its national interest, it started seeing itself an undisputed world power, capable of mobilizing militarytechnological facilities in any region and securing control of any resource by dominating its allies, isolating adversaries and sustaining the client regimes. Analytically, the massacre of September 11 became a starting point for the US to launch the second version of the New World Order (Petras, 2002). The ascent of new great powers is the strongest evidence of incipient multipolarity, and the two most important indicators of whether new great powers rising are relative growth rates and shares of world GDP (Kennedy 1987; Gilpin 1981) (in Layne, 2011: 151). 
The contemporary world is a world of multiple powerful actors on the global and regional levels, with conflicting interests, economic difficulties of large number of economies, and the inability of the "international community" to put a stop on the world's most intense conflicts or rivalries. The world is unable to solve some of its worst security crises that is a fact that represents a repetition of modern history.

Is the fact that the world has become more multipolar responsible for its inability to solve the most serious crises? And what are the causes of this multipolarity?

The main hypotheses of the paper are the following:

1) Multipolarity can be connected with «asianisation» in the economy in its large part, and consequently political power. The «asianisation» of the popular culture and the military power is far slower, albeit the fact that large Asian states are narrowing the gap on these fields too;

2) The future will bring the continuation of the present processes. For us, two are the most important: the rise of contenders will be more rapid than the rise of dominant states, and the role of the nation state/national economy will not decrease, thereby creating conditions for a truly multipolar world in the first half of the $21^{\text {st }}$ century.

Multipolarity, as an ever changing process (and a condition which represents a timeframe of this continuous process), essentially functions as a struggle between dominant and contender states through processes of uneven development (Harvey, 1995) or simultaneous processes of uneven and combined development (see Desai, 2013). In the $20^{\text {th }}$ century, historical shifts between attempted unipolarity/hegemony and resulting multi-polarity exactly witnessed the struggle between national economies of the dominant, developed states and the contender states (in the contemporary world, socalled emerging economies of the large non-Western states).

Considering the hypotheses that are set forth in this paper in studying and explaining multipolarity, it will be viewed primarily as an outcome of combined development caused shifts in the geographical (from Europe and North-America to Asia, and in a less degree Latin America) and cultural (from Western to non-Western states i.e. societies) distribution of economic power and consequently political and military power.

\section{Discussion}

\subsection{The origins of the contemporary multipolarity: geographical and cultural re- distribution of economic power}

The unipolar era already is visibly drawing to a close. Three main drivers explain the impending end of the Pax Americana. First, the rise of new great powers - especially China-is transforming the international system from unipolarity to multipolarity. Second, the United States is becoming the poster child for strategic over-extension, or as Paul Kennedy (1987) dubbed it, imperial overstretch. Third, the United States' relative economic power is declining. In particular, mounting US fiscal problems and the dollar's increasingly problematic role as the international financial system's reserve currency are undermining US hegemony (Layne, 2011: 150).

The question of possible US decline could not be answered using the dominant International Political Economy (IPE) paradigms of the day, but that a thorough rethinking of how to make sense of US power in the global political economy was necessary. Gill (1990: 42) also broke from the theory of US decline. His neo-Gramscian perspective revised the category of hegemony not as simply a physical capability such as military might and economic weight, but as 'intellectual and moral leadership' (Parisot, 2013: 1160).

The economic power of the world has undeniably spread outside of (Western) Europe and North America, making the East, South and Southeast Asia the workshops of the world. China has to be credited for that the most ${ }^{\text {ti }}$. That does not mean that the era of Western role has shifted to China and East Asia exclusively. Nevertheless, it has spread and it now include several centers other than the West: We do not see so much a recentering of the global economy in East Asia, as Arrighi and Silver (1999: 219) claim, as much as a decentering of the global economy; its fragmentation and the rise of several zones of intense global accumulation (Robinson, 2005:9).

Demographic capacity outside the Western, developed world, has become economic power. Hundreds of millions of people have become industrial workers, albeit very large proportions of the people in these regions still sustain on agriculture. Therefore, if we consider the economic power and its distribution around the world, maybe it is better to 
speak of an "asianisation" instead of a globalization iii. The current economic crisis, which hit the developed, especially European economies the hardest, has shifted more economic power into the direction of emerging economies, thereby accelerating an inevitable economic and political change. This crisis can be characterized as a manifestation and a booster of combined development. The crisis also has unavoidable cultural implications, since some, mainly Asian, excolonies have managed to accelerate the change in the distribution of economic wealth. These states, grouped mainly in BRICS, and in the Next Eleven (N11), have shown, contrary to the Western, culturally "superior" and racist geopolitical thought, that they are not backward or incompetent, thereby challenging the developed states. The globalization paradigm also has to be rejected since the role of dominant and contender states in contemporary world has remained firm, and the world is marked by the struggle between these two groups of states and not "flattening by the globalization". Besides that, the inequality (measured by GINI index) in most of the states of the world has increased and not decreased, and is increasing. Therefore, the notions about the "flat world" (see Friedman, 2008) do not describe the reality of the present day world.

The authors that can definitely not be characterized as the proponents of globalization, Harvey, as well as Hirst and Thompson, agree with T. Friedman on the existence of three globalizations: For Harvey (1995) and for Hirst and Thompson (1996), the geography of capitalism has constantly experienced a process of globalization since its emergence in the sixteenth century (during the Age of Exploration), and a careful historical analysis would suggest that the period from 1870 to 1914 experienced even greater attributes of globalization than the current period of supposed interdependencies. Thus, for Harvey (1995: 8), a more appropriate term for the current "globalization" would be the "process of production of uneven temporal and geographic development" cautionary tone, contemporary capitalism has witnessed a "limited qualitative change" in comparison to the era of previous globalization in the late $19^{\text {th }}$ and early $20^{\text {th }}$ century (Ibid: 12) (in:Samers, 1999: 168). From the citation, we can see that the current globalization can be characterized as even a bit less globalist, considering the level of supposed interdependencies. Nevertheless, what is more important for the purpose of this paper is Harvey's thesis of the "process of production of uneven temporal and geographic development". Capitalism has indeed experienced a "limited qualitative change", adopting itself to contemporary conditions, mainly in the developed states of Europe and North America. However, its goals have remained the same, since they are comprised in its own nature. Besides that, in the underdeveloped states of Africa and Asia, where neoliberalism has quickly spread ${ }^{v}$, capitalism has remained brutal. In many developing states, the working conditions and living standard look like the working conditions and standard of the workers and miners of the $19^{\text {th }}$ century Europe.

Desai (2013: 2-3, 10-11) uses the term "uneven development" adding to it the term "combined development", stating that the processes of uneven and combined development (UCD) predominantly characterize the modern world, and states are the ones that hold the dominant role in these processes in spite of the paradigm of globalization that claims otherwise. States dominate the political economy on the domestic level, and geopolitical economy on the international level. Therefore, Desai's thesis on geopolitical economy is that it is a product of uneven and combined development. UCD refers to the fact that on the one hand, dominant states tend to, including through means of formal and informal imperialism, preserve existing uneven configurations of capitalist development which favor them; whereas on the other hand, contender states accelerate capitalist and, such as in the case of the USSR, have accelerated communist development, all in order to contest the imperial projects of the dominant states ${ }^{\mathrm{vi}}$.

Robinson (2002) however argues that globalization has arisen as a product of the rise of transnational capital and a transnational capitalist class, and has been facilitated by the revolution in communications technologies and transportation, which has created a genuinely global, as opposed to international economy. This global economy is characterized by capital mobility, globalized circuits of accumulation, and the fragmentation of production. Globalisation thus mainly refers to new forms of organizing capitalist production beyond the territorial boundaries of the nation state, and is therefore related to post-Fordist restructuring since the 1970s. This is reflected in increased direct foreign investment, including mergers and acquisitions between firms originating in different countries, the increased practice of subcontracting and outsourcing by companies to (local and foreign) suppliers, and the increase in trade between two or more subsidiaries of the same parent company (Robinson 2004, 18, 23-24, 58, 55) (Kiely, 2006: 206). Nevertheless, Robinson's theses about transnational capital and class do not stand in opposition with the thesis of Harvey. Harvey (2005: 11) broadly frames neoliberalism as a project primarily aimed at freeing capital from the constraints imposed by these "embedded liberalisms", and more directly as a process ultimately focused on restoring the class power of economic elites (Buckley, 2013: 259). What we are left with is a transnational capitalist class (Harvey, 2005: 11). The fact that the contender states are rising more rapidly and that the state had to intervene (and 
still has in many countries) during the present economic crisis does not mean that transnational capitalist class is not pursuing its interests. Most interventions of the state in developed countries, such as the U.S.A. and the countries of the European Union (especially the European Monetary Union) were actually aimed at saving this class, through bailouts of mostly privately owned banks.

\subsection{The Contemporary Multipolarity}

Multipolarity, an object of study of the geopolitical economy (Desai, 2015: 2), can in historical sense be viewed as the next step in the process of hegemonic decline of a particular dominant state (the United Kingdom, and then the United States), considering the fact that their economic growth has experienced slowing down, stagnation, and in some shorter historical period even recession or depression. The inability to change i.e. adapt to new conditions had produced the downfall of hegemonic states ${ }^{\text {vii }}$, transforming hegemony/unipolarity into multipolarity. The process of combined development has been the primary accelerator of multipolarity, since the contender states have managed to shrink the gap between the developed states and themselves. On the other hand, the dominant states, are not willing to give up on their position, even in the various international institutions, especially financial.

As an example, we can emphasize that the fact that emerging economies are rapidly narrowing the gap that divides them from the developed states has not yet reflected in the voting mechanisms of the Bretton Woods financial institutions. Desai and Vreeland (2010: 110) state: In 2003, for the first time since the nineteenth century, the share of the global economy held by the 21 richest countries fell below 50\%. The US share has fallen below 20\%. More importantly, while the wealthiest countries' share of global economic growth remained at around $50 \%$ between 1960 and 2000, it has fallen to just over $25 \%$ in the past decade. Change at the IMF has not kept pace (Buira 2005; Woods

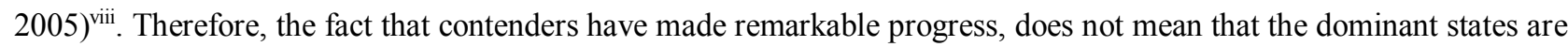
ready to surrender their position. They are revoking only a bit of their power ${ }^{\text {ix }}$, slowly, while doing everything to slow the contenders' pace.

The economic crisis also produced criticism of another feature of the international monetary system: the central role of the dollar ${ }^{\mathrm{x}}$. During the 2008-2009 financial crisis, China's criticism of the dollar's role appeared to aim at a strengthened multilateral system, not an overthrow of that system. The Chinese monetary agenda included many ideas that were familiar from earlier discussions of monetary reform, paralleling European criticisms from the Bretton Woods era. Chinese representatives did not raise these issues forcefully at G20 summits, however; nor did China or the other emerging economies appear to aim at a new global monetary architecture. A more significant option, promoted by China (though not by India or Brazil), was the internationalization of its currency with the aim of creating an alternative to the dollar (Kahler, 2013: 714) ${ }^{\mathrm{xi}}$. Nevertheless, the BRICS states are pursuing their own investment bank and solutions that would break the dominant position of Breton Woods's institutions.

At the same time, there are voices even in the West who are advocating different solutions to the economic crises, present and future: A key factor for any global solution will be the inclusion of the powerful emerging economies of the South. Growing sectors of transnational capitalists have been accepting the need to bring China, India, Brazil and other countries into the inner circles of decision making. This will be easier to accomplish under the multilateral approach of the Obama globalists than the Bush unilateralists. Even World Bank president Robert Zoellick and IMF chief Dominique Strauss-Kahn have spoken on the need to give more say to the South in their respective institutions. This is a necessary recognition of a changed world (Harris, Davidson, 2010: 225).

Haass (2008) argues that the global system has now embarked on a 'quasi-anarchic journey' that involves more than state actors and includes NGOs, large corporations, terrorists and energy providers. He concludes that an open challenge by a single emerging power or coalition of powers "is unlikely to arise anytime soon". He calls this system nonpolarity (Haass, 2008: 44).

\subsection{Present and future developments: the state is definitely back, further gradual shift of power towards Asia-Pacific, the rising importance of multipolarity}

In 2008, Zakaria published a book "The Post-American World", just when the financial meltdown has taken momentum. He predicted a relative decline of American power in the next couple of decades, mainly because of the rise of the contenders. He also advised the orientation towards soft-power to the U.S. policy-makers. 
In 2009, Clark still believed that a concentration of power will still last for a couple of decades: At present, no single version of hegemony ${ }^{x i i}$ seems viable on its own. As a composite, these types map out a hegemonic project that is respectful of the diversity in international society, its traditional nervousness about too much concentration of power, and its already existing expressions within the highly developed western system. At the same time, it acknowledges that a concentration of power is, whether we like it or not, an inescapable constituent of contemporary order. (...) A different world may possibly emerge in the next 20-30 years, but what is needed is an effective blueprint for action in the interim. In meeting this challenge, hegemony has its own distinctive contribution to make (Clark, 2009: 36).

The most frequently cited vision of a competitive multipolar system is Robert Kagan's The Return of History (2008), which argues that the ability of the US to maintain the international order is declining (Kagan, 2008: 3). He points out that after the Cold War, the US pursued "an expansive, even aggressive global policy", and that "in shaping a world to suit their values, they have compelled others to bend to their will" in ways that were bound to create a backlash. The logic is that all great powers are arrogant - it just so happens that, for a while, the US was the only one around. For this reason, rising powers will tend to create a balance against the US (Toje, 2010: 12) xiii. $^{\text {. }}$

In the 2025 Global Report: A Transformed World, published by National Intelligence Council (NIC)in November 2008, the resurgence of the state in economic affairs, particularly for the rising powers, is pointed. As with previous countries whose economies had taken off, such as South Korea and Taiwan in the 1960s and 1970s, the state is playing an important economic role not just in authoritarian states like China, but arguably even in rising democracies like Brazil and India. The financial crisis would seem to have further heightened the role of the state, potentially even more so where governments in the West are funding bailouts and coordinating stimulus packages ${ }^{\mathrm{xiv}}$.

This development is in the accordance with the notion about "the crisis of neoliberalism": Since the 2007 financial meltdown, the neoliberal project has been in crisis. Even some of its most ardent supporters have begun to rethink its legitimacy. Yet neoliberalism remains hegemonic, underpinning a host of policy rhetoric and initiatives aimed at stemming recessionary declines (Lauermann, Davidson, 2013: 1277). Nevertheless, Hess (2011: 1058-59) stated: Although the effects of the Great Recession on politics and economics are not yet known, some of the policies associated with the Democratic Party's control of the US government in 2009 suggest a partial turn away from neoliberalism $^{\mathrm{xv}}$. Deficit spending, health-care reform, regulation of the financial sector, new educational programs, green economic development, and carbon-trading are all policy directions that suggest at least a partial return to higher levels of state intervention in markets, albeit ones that often cede significant ground to neoliberal approaches in the construction of policy instruments ${ }^{\mathrm{xvi}}$. So, neoliberalism has been on the retreat in some areas, but it is still advancing are the rescue attempts done by the state in order to save private banks really a retreat of neoliberalism or its final victory?

The crisis has underscored the importance of globalization as the overriding force or "mega-driver" as it was characterized in both the NIC's 2020 and 2025 Global Trends works. Developing countries have been hurt as decoupling theories, assertions that the emerging markets have appreciably weaned themselves from the U.S. economy, have been dispelled. At the same time, globalization itself may be transformed because of the financial crisis. The spectacular growth in global liquidity that took effect in the past decade, allowing for an era of free money, may be ending. Recent data suggests that the NIC may have underestimated the extent and pace of the contraction in global trade, at least in the short term, and the corresponding diminished appetite for Chinese manufactures (Burrows, Harris, 2009: 27-28).

The latest NIC report, Global Trends 2030: Alternative Worlds ${ }^{\mathrm{xvi}}$, published in December 2012, at the very beginning clearly states: The world of 2030 will be radically transformed from our world today. By 2030, no country-whether the US, China, or any other large country — will be a hegemonic power. The empowerment of individuals and diffusion of power among states and from states to informal networks will have a dramatic impact, largely reversing the historic rise of the West since 1750, restoring Asia's weight in the global economy, and ushering in a new era of "democratization" at the international and domestic level ${ }^{\text {xviii. }}$

Relative weight of top corporations (by number, sales, assets, and profits) - remains quite low (although higher in Russia and South Africa than in the other three) - rising in all cases, but low nonetheless. This suggests that we are at the beginning, not the end of a process. China's "leap" into prominence in the world system has only begun the process of addressing the massive unevenness characteristic of that system (Kellogg, 2015: 289). 
If we take into account the fact that China and Russia, as main contender states, are rapidly modernizing and continuing to build their own military arsenal, especially navy and air transport capabilities, we cannot exclude the possibility of a future arms race between the U.S.A. on one side, as the main dominant state, and these two contender states. The U.S.A. could again go through the period of what Seymour Melman called "Pentagon capitalism", as the "state management" typified by the actions of Secretary of Defense Robert McNamara drew an ever-tighter loop around economic, military, and political authority (in: Farish, Vitale, 2011: 778). The US military-industrial complex could again be the main driver of capitalist economy and the pursuit of the United States for military presence in any part of the world. Especially is a particular region is considered to be of the interest for the United States (that is actually almost the whole world, although some regions hold a special importance, such as the Middle East ${ }^{\mathrm{xix}}$ and the North Africa region and the Asia-Pacific region).

\section{Conclusion}

No matter what version of hegemonic stability theory (HST) we accept or completely reject (with its main thesis that hegemonic power brings stability and order in the system, from which not only the hegemon, but also smaller states benefit, more or less ${ }^{\mathrm{xx}}$ ), and instead accept multipolarity and a contestation between the dominant and contender states as an inevitable condition in the $21^{\text {st }}$ century, it is very difficult to imagine that the U.S.A. will not continue to pursue its own hegemony, albeit the success of this pursuit would definitely not be positive. However, we have to keep in mind that HST also claims that instability occurs in the system when a certain hegemon is losing its grip on hegemony (HST finds confirmations in the situation that preceded the two World Wars, and stagflation in the 1970ies). Nevertheless, a real hegemony, understood in a neorealist, neoliberal or even Gramscian sense, would not be possible in the future.

The current economic crisis could also be viewed as a process in which former hegemon continues to lose its grip on the world order, after a period in the 1990ies and the first half of the 2000ies, when it tried to exploit the power vacuum after the collapse of the U.S.S.R. and desired to establish a hegemony through the paradigms of Globalization and Empire.

Multipolarity is a realism of the contemporary and the future world (increasingly). What is needed is a multifarious, multifaceted approach to multipolarity, which would accept that the hegemony of one power (if there ever was one) is outdated, never to return.

\section{References}

- Arrighi, G., Silver, B. J. (1999). Chaos and Governance in the Modern World System. University of Minnesota Press, Minneapolis.

- Bozdağlığlu, Y. (2013). Hegemonic (in)Stability Theory and Us Foreign Policy: The Legacy of the Neocons in the Middle East. Anadolu University Journal of Social Sciences, 13 (3) 1-12.

- Buckley, M. (2013). Locating Neoliberalism in Dubai: Migrant Workers and Class Struggle in the Autocratic City. Antipode, 45 (2) 256-274, CrossRef

- Buira, A. (2005). Reforming the Governance of the IMF and the World Bank. Anthem Press, London.

- Clark, I. (2009). Bringing hegemony back in: the United States and international order. International Affairs, 85 (1) 23-36, CrossRef

- Cox, R. W. (1987). Production, Power and World Order: Social Forces in the Making of Modern History.Columbia University, New York.

- Desai, R. (2013). Geopolitical Economy: After US Hegemony, Globalization and Empire. The Future of World Capitalism. Pluto Press, London, and Fernwood Publishing, Halifax and Winnipeg.

- Desai, R. (2015). Geopolitical Economy: the Discipline of Multipolarity. Valdai Papers, (24) 1-12.

- Desai, R. M., Vreeland, J. R. (2010). Are Davos Man's Days Numbered? Up Front Blog. The Brookings Institution. 26 January.

- Desai, R. M., Vreeland, J. R. (2011). Global Governance in a Multipolar World: The Case for Regional Monetary Funds. International Studies Review, (13) 109-121, CrossRef

- Dilip Hiro, S. (2008). The Sole Superpower in Decline: The Rise of a Multipolar World. Military Review, July-August, 109-113.Reprint of text inJournal of the United Service Institution of India, 137 (569). 
- Dollar, D., Kraay, A. (2002). Growth is good for the poor. Journal of Economic Growth, (7) 195-225, CrossRef

- Farish, M., Vitale, P. (2011). Locating the American Military-Industrial Complex: An Introduction. Antipode, 43 (3) 777-782, CrossRef

- Friedman, T. (2008). The World isflat. Farrar, Straus \& Giroux, New York.

- Gill, S. (1990). American Hegemony and the Trilateral Commission. Cambridge University Press, New Yo

- Gilpin, R. (1987). The political economy of international relations. Princeton University Press, Princeton, NJ, CrossRef

- Haass, R.N. (2008). The age of nonpolarity. Foreign Affairs, 87 (3) 44-57.

- Harris, J., Davidson, C. (2010). Obama: The New Contours of Power. Perspectives on Global Development \& Technology, (9) 211-231.

- Harvey, D. (1995). Globalization in question. Rethinking Marxism,8 (4) 1-17, CrossRef

- Harvey, D. (2005). A Brief History of Neoliberalism. Oxford University Press, New York.

- Hess, D. J. (2011). Electricity Transformed: Neoliberalism and Local Energy in the United States. Antipode, 43 (4) 1056-1077, CrossRef

- Hirst, P., Thompson, G. (1996). Globalization in Question. Polity Press, Oxford.

- $\quad$ https://globaltrends2030.files.wordpress.com/2012/11/global-trends-2030-november2012.pdf

(Retrieved 14.06.2015).

- Joseph, J. (2002). Hegemony: A Realist Analysis. Routledge, London and New York, CrossRef

- Kagan, R. (2008). The return of history and the end of dreams. Knopf Publishing, New York.

- Kahler, M. (2013). Rising powers and global governance: negotiating change in a resilient status quo. International Affairs, 89 (3) 711-729, CrossRef

- Kellogg, P. (2015). Geographies of Capital Accumulation: Tracing the Emergence of Multi-polarity, 1980 2014. In: Theoretical Engagements in Geopolitical Economy. Published online: 22 Sep 2015; 259-294.

- Kennedy, P. (1987). The rise and fall of the great powers: economic change and military conflict from 1500 to 2000. Random House, New York.

- Keohane, R. A. (1984). After Hegemony: Cooperation and Discord in the World Political Economy. Princeton University, Princeton.

- Kiely, R. (2006). United States Hegemony and Globalisation: What Role for Theories of Imperialism? Cambridge Review of International Affairs, 19 (2) 205-221, CrossRef

- Kirshner, J. (2008). Dollar primacy and American power: what's at stake? Review of International Political Economy, 15 (3) 418-438, CrossRef

- Lauermann, J., Davidson, M. (2013). Negotiating Particularity in Neoliberalism Studies: Tracing Development Strategies across Neoliberal Urban Governance Projects. Antipode, 45 (5) 1277-1297, CrossRef

- Layne, C. (2011). The unipolar exit: beyond the Pax Americana. Cambridge Review ofInternational Affairs, 24 (2) $149-164$.

- Lin, J. Y., Dailami, M. (2011). The Coming Multipolar World Economy: Is the Developed World Prepared? The International Economy, 30-31.

- Magdoff, H. (2003). Imperialism without colonies. Monthly Review Press, New York.

- Mercille, J. (2008). Mind the Gaps: Security 'Crises' and the Geopolitics of US Military Spending. Geopolitics, 13 (1) 54-72, CrossRef

- Monshipouri, M., Assareh, A. (2011). The New Middle East and the United States: What to Expect after the Uprisings? Insight Turkey, 13 (3), 121-138.

- Parisot, J. (2013). American Power, East Asian Regionalism and Emerging Powers: in or against empire? Third World Quarterly, 34 (7) 1159-1174, CrossRef

- Petras, J. (2002). 9/11: one year of empire building. Economic and Political Weekly, 37 (3) 504-514.

- Prashad, V. (2012). The Poorer Nations: A Possible History of the Global South. Verso, New York.

- Robinson, W. (2002). Capitalist Globalization and the Transnationalization of the State. In: Rupert, M., Smith, H. (eds.) Historical Materialism and Globalization. Routledge, London: 210-229.

- Robinson, W. (2004). A Theory of Global Capitalism. Johns Hopkins University Press, Baltimore, MA.

- Robinson, W. (2005). Gramsci and Globalisation: From Nation State to Transnational Hegemony. Critical Review of International Social and Political Philosophy, 8 (4) 1-16, CrossRef 
- Samers, M. (1999). 'Globalization', the geopolitical economy of migration and the 'spatial vent'. Review of International Political Economy, 6 (2) 166-199, CrossRef

- Snidal, D. (1985). The Limits of Hegemonic Stability. International Organization, 39 (4) 579-614, CrossRef

- Toje, A. (2010). The Tragedy of Small Power Politics: The European Union under Multipolarity. Security Policy Library 4-2010. The Norwegian Atlantic Committee, Oslo.

- UNDP. (2002). Human Development Report: Deepening Democracy in a Fragmented World. Oxford University Press, New York.

- Wade, R. H. (2003). Is globalization reducing poverty and inequality? International Journal of Health Services, (34) 381-414.

- Webb, M. C., Krasner, S. D. (1989). Hegemonic Stability Theory: An Empirical Assessment. Reviewof International Studies, 15 (2) 183-198, CrossRef

- Woods, N. (2005). Making the IMF and the World Bank More Accountable. In: Buira, A. (ed.), Reforming the Governance of the IMF and the World Bank. Anthem Press, London.

- Zakaria, F. (2008). The Post-American World. W.W. Norton \& Company, New York.

- Zoellick, R. B. (2010). The End of the Third World: Modernizing Multilateralism for a Multipolar World. The International Economy. Spring 2010, http://www.international-economy.com/TIE_Sp10_Zoellick.pdf (Retrieved 16.08.2015)

\footnotetext{
${ }^{i}$ The hegemonic power is therefore self-interested in creating and spreading the rules, institutions and values that will foster the internationalization of capital. Moreover, it often finds it necessary to use its military power as "global policeman" to protect the international system against external threats and internal rebellions (Mercille, 2008: 58).

\begin{abstract}
ii When Germany industrialized in the late 19th century, it transformed the geography of world capitalism. When Japan recovered from the devastation of World War II, the geography of the world economy was similarly transformed. We are at the beginning of another such transition. Given the size of the country involved, it is likely to be bigger and more important than the transitions associated with the emergence of either Germany or Japan (Kellogg, 2015: 287).
\end{abstract}

iiiBy 2025, six emerging economies — Brazil, China, India, Indonesia, South Korea, and Russia—will collectively account for about one-half of global growth. (Lin, 2011: 30).

${ }^{\text {iv }}$ While neoliberal proponents suggest that absolute poverty levels have declined since the early 1980s (Dollar and Kraay, 2002), the reliability of such statistics has come under fire (Wade, 2003). Poverty reduction statistics do not recognize spatial and temporal variations in inflation or purchasing power, and if China is excluded, the 1990s actually show an increase in global poverty (UNDP, 2002).

$\mathrm{v}$ 'The expansion of neo-imperialism occurred not only through the policies of states, but also through the actions of corporations and the mechanisms of trade, finance and investment' (Magdoff, 2003: 15).

viSuch hothouse development is called combined development because it combines or compresses many development stages into shorter and more intense bursts. Despite the economic, geopolitical, military and ideological power marshalled by dominant states, UCD has so far been dominated by the latter - sometimes against great odds and with apparently interminable delays.

vii With the collapse of the Soviet Union in 1991, the United States stood tall-militarily invincible, economically unrivalled, diplomatically uncontestable, and the dominating force on information channels worldwide. The next century was to be the true "American century," with the rest of the world moulding itself in the image of the sole superpower. Yet, with not even a decade of this century behind us, we are already witnessing the rise of a multipolar world in which new powers are challenging different aspects of American supremacy_Russia and China in the forefront, with regional powers Venezuela and Iran forming the second rank. These emergent powers are primed to erode American hegemony, not confront it singly or jointly (Dilip Hiro, 2008: 109).

\footnotetext{
viii Although the wealthiest countries' voting shares on the IMF's Executive Board are now roughly on par with their economic power (that is about $41 \%$ ), there are notable imbalances: in particular, the fastest-growing developing nations with large economies are woefully underrepresented. China has about three quarters the vote shares of France even though China's economy is larger by a factor of four. Yet, the G-20 is not a viable alternative. It is not much more representative than the current Executive Boards of the IMF and the World Bank. In addition to a European Union seat, there are seats for Germany, France, the United Kingdom, Italy, and the next largest economies of Europe, the Netherlands and Spain, have lobbied for de facto representation at G-20 summits (Desai, Vreeland, 2010: 111).
} 


\begin{abstract}
ix In bargaining with the incumbent powers, China and other emerging economies have possessed one key asset: their large levels of reserves, accumulated as insurance against international financial shocks and as an effect of undervalued exchange rates. China's reserves in particular have exploded in size over the past decade. Although growing monetary power awarded it greater influence at the IMF, China's efforts to use its reserves as bargaining assets in bilateral negotiations with the United States have been largely ineffective (Kahler, 2013: 720).
\end{abstract}

x The dollar's vulnerability presents 'potentially significant and underappreciated restraints upon contemporary American political and military predominance’ (Kirshner, 2008: 418).

xi The meltdown has amplified doubts about the dollar's future in two key respects. First, the other big players in the international economy now are either military rivals (China) or ambiguous 'allies' (Europe) that have their own ambitions and no longer require US protection from the now-vanished Soviet threat. Second, the dollar faces an uncertain future because of concerns that its valuewill diminish over time. Indeed, China, which has vast holdings of American dollars (more than $\$ 2$ trillion) is worried that America's fiscal incontinence will leave Beijing holding the bag with huge amounts of depreciated dollars. (Layne, 2011: 156-7).

xii What is meant by this hegemony? It does not refer simply to a set of material conditions in which one state is predominant: it is not, in other words, primacy alone. Neither is it something that is unilaterally possessed by the hegemon, nor something that the dominant state has in its pocket, to save or squander at will. Rather, it is a status bestowed by others, and rests on recognition by them. This recognition is given in return for the bearing of special responsibilities. In short, by hegemony is meant an institutionalized practice of special rights and responsibilities conferred on a state with the resources to lead. (Clark, 2009: 23).

xiii In Kagan's argument, the twenty-first century international system will resemble mid-nineteenth-century Europe. That would mean a period of bare-knuckle national interest politics with a minimum of postmodern padding. This is the scenario that the US National Intelligence Council has labelled "multipolarity without multilateralism". From this perspective, great power geopolitical rivalries will deepen in the same patterns as ideological rifts between autocracies and democracies. Rising powers will seek to improve their relative positions and establish hegemony along their borders. As the emerging powers grow in strength, the area they define as their national interest will expand, causing friction with other powers. Because their envisioned spheres of influence will overlap, the relationship between the great powers is likely to be competitive. This is a classic balance-of-power argument. It draws on the classical realist view of history and a neorealist focus on structure (Toje, 2010: 12).

xiv The question is whether this enhanced economic role for the state will be a permanent, enduring feature of the future economic landscape or one that is transitory until some economic stability is achieved and growth resumes. The answer may be slow to emerge, as none of these models of state and market appear close to a steady equilibrium. As those "newly rich" states that willingly collapsed distinctions of public and private now bleed reserves, and as Western governments come to wrestle the costs of fiscal stimulus amid continued economic uncertainty, societies everywhere will repeatedly confront the need to define and redefine the desired role of the state in markets (Burrows, Harris, 2009: 30-31).

${ }^{x v}$ While remaining supporters of expanding trade and transnational integration, Nobel prize-winning economists Joseph Stiglitz and Paul Krugman have, for the past decade, called for greater financial regulation and attention to global inequalities. Although having limited representation in the Obama administration, progressives exert constant pressure through their voice to the broader public. Krugman suggests the global slump can be fixed, at least in part, with public works' spending. As he says: 'The answer, almost surely, is good old Keynesian fiscal stimulus.' (Harris, Davidson, 2010: 217).

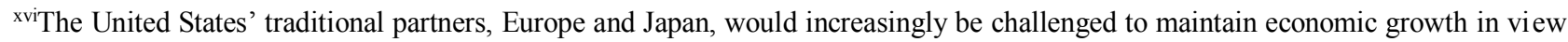
of their aging populations. While the rising states would want seats at the international high table, the report anticipated that they would be cautious about assuming global burdens, despite a packed agenda composed of new challenges like climate change and energy security in addition to growing threats such as nuclear proliferation and weapons of mass destruction (WMD) terrorism. By 2025 the international order, although unrecognizable from its post-World War II contours, would remain in transition and be one in which the United States, though still preeminent, would be less dominant even as others would still look to it to shoulder many of the global burdens (see Burrows, Harris, 2009: 27).

\title{
xviihttps://globaltrends2030.files.wordpress.com/2012/11/global-trends-2030-november2012.pdf.
}

xviii (...) We believe that two other megatrends will shape our world out to 2030: demographic patterns, especially rapid aging; and growing resource demands which, in the cases of food and water, might lead to scarcities. These trends, which are virtually certain, exist today, but during the next 15-20 years they will gain much greater momentum.

xix The Middle East has been the major focus of American foreign policy and will continue to be so. During the Cold War, the US, for the sake of security and stability, did not hesitate to back up repressive regimes in the region. After the Cold War, the US continued to support pro-West regional dictators out of the fear that Islamic fundamentalists would seize the power if democracy 
was allowed. In the post-September 11 era, the US policy in the MENA countries was shaped by "the fight against terrorism" (Monshipouri and Assareh, 2011, p. 123).

The Bush Doctrine and its application to first Afghanistan and later Iraq change the balance of power and the social structure in the region forever creating serious destabilizing effects in the region. (...) The existence of only one superpower, call it a hege mon or an empire, does not guarantee security and stability. Furthermore, as is the case for American involvement in the Middle East, it can be the source of insecurity and instability (Bozdağlıoğlu, 2013:2).

${ }^{x x}$ Public goods version of theory or security version of theory. See: Snidal, 1985, Webb and Krasner, 1989, in: Bozdağlioğlu, 2013 : 4-5). 